\title{
PUSAT BUDAYA MELAYU KALIMANTAN BARAT
}

\author{
Waldi Apriadi ${ }^{1}$, Uray Fery Andi², Zairin Zain ${ }^{3}$ \\ ${ }^{1}$ Mahasiswa, Program Studi Sarjana Arsitektur, Fakultas Teknik, Universitas Tanjungpura \\ waldiapriadi@gmail.com \\ ${ }^{2}$ Program Studi Sarjana Arsitektur, Fakultas Teknik, Universitas Tanjungpura \\ ${ }^{3}$ Program Studi Sarjana Arsitektur, Fakultas Teknik, Universitas Tanjungpura
}

Naskah diajukan pada: 22 Februari 2021

Naskah revisi akhir diterima pada: 14 Maret 2021

\begin{abstract}
Abstrak
Telah banyak upaya para pelaku budaya lakukan untuk memajukan dan melestarikan Budaya Melayu di Kalimantan Barat, namun masih mendapatkan kendala yang membuat semuanya terhambat. Seperti minat generasi penerus untuk mempelajari dan melestarikan Budaya Melayu semakin berkurang, kegiatan promosi budaya yang seadanya, pemasaran kerajinan khas yang sulit dipasarkan, dan komunitas Budaya Melayu belum memiliki tempat yang layak untuk berkarya.Mengantisipasi hal tersebut maka diperlukan suatu wadah untuk melestarikan, memperagakan, mempertahankan dan mengembangkan Budaya Melayu Kalimantan Barat. Proyek tugas akhir Pusat Budaya Melayu bertujuan menciptakan wadah untuk pelestarian Budaya Melayu di Kalimantan Barat secara terpusat. Metode perancangan Pusat Budaya Melayu Kalimantan Barat dilakukan dalam beberapa tahap yaitu gagasan, tinjauan teori, pengumpulan data, analisis, sintesis, pra rancangan, dan perancangan. Konsep perancangan Pusat Budaya Melayu didasarkan pada elemen perancangan kawasan permukiman Melayu. Analisis perancangan menghasilkan beberapa fungsi bangunan namun secara garis besar terbagi menjadi tiga fungsi, yaitu fungsi primer (gedung pertunjukan), fungsi sekunder (gedung latihan, gedung galeri seni), dan fungsi pengelola (gedung pengelola, kios souvenir). Analisis pembentukan pola kawasan diambil dari unsur pembentukan kawasan melayu pada umumnya dan dipadukan dengan bentuk lokasi perancangan. Karakteristik bangunan mengikuti bentuk permukiman Melayu Kalimantan Barat berupa khas bangunan panggung dan atap limas/pelana dengan ruang yang disesuaikan dengan kebutuhan pengguna.

Kata-kata Kunci: Pusat Budaya Melayu, Budaya Melayu, Melayu Kalimantan Barat.
\end{abstract}

\begin{abstract}
There have been many attempts by cultural actors to promote and preserve Malay Culture in West Kalimantan, but they still face obstacles that make everything hampered. As the interest of the next generation to study and preserve Malay Culture is decreasing, cultural promotion activities are modest, marketing of typical handicrafts that are difficult to market, and the Malay Culture community does not yet have a suitable place to work. Anticipating this, a forum is needed to preserve, demonstrate, maintain and develop West Kalimantan Malay Culture. The final project of the Malay Cultural Center aims to create a center for the preservation of Malay Culture in West Kalimantan. The design method of the West Kalimantan Malay Cultural Center was carried out in several stages, namely ideas, theoretical review, data collection, analysis, synthesis, pre-design, and design. The design concept of the Malay Cultural Center is based on the design elements of the Malay settlement area. The design analysis resulted in several building functions but broadly divided into three functions, namely primary function (performance building), secondary function (training building, art gallery building), and management function (management building, souvenir kiosk). Analysis of the formation of the pattern of the area is taken from the elements of the formation of the Malay area in general and is combined with the shape of the design location. The characteristics of the building follow the form of a West Kalimantan Malay settlement in the form of a typical building on stilts and a pyramid roof/saddle with space tailored to the needs of the user.
\end{abstract}

Keywords: Malay Cultural Center, Malay Culture, Malay West Kalimantan

\section{Pendahuluan}

Menurut Koentjaraningrat (2000:181), kebudayaan dengan kata dasar budaya berasal dari bahasa sansakerta "buddhayah", yaitu bentuk jamak dari buddhi yang berarti "budi" atau "akal". Jadi 
Koentjaraningrat mendefinisikan budaya sebagai "daya budi" yang berupa cipta, karsa dan rasa, sedangkan kebudayaan adalah hasil dari cipta, karsa, dan rasa itu. Koentjaraningrat menerangkan bahwa pada dasarnya banyak yang membedakan antara budaya dan kebudayaan, dimana budaya merupakan perkembangan majemuk budi daya, yang berarti daya dari budi. Pada kajian Antropologi, budaya dianggap merupakan singkatan dari kebudayaan yang tidak ada perbedaan dari definisi. Jadi kebudayaan atau disingkat budaya, menurut Koentjaraningrat (2000) merupakan keseluruhan sistem gagasan, tindakan dan hasil karya manusia dalam rangka kehidupan masyarakat yang dijadikan milik diri manusia dengan belajar.

Penduduk asli Kalimantan Barat adalah suku (etnis) Dayak. Suku Dayak ini terbagi atas beberapa subsuku berdasarkan perbedaan bahasa seperti: Dayak Barat, Dayak Malayic, Dayak Iban, Dayak Taman, Dayak Punan, dan Dayak Ut Danum. Suku Melayu dibagi menjadi beberapa subsuku berdasarkan dialeknya seperti: Melayu Sambas, Melayu Ngabang, Melayu Pontianak, Melayu Mempawah dan Melayu Ketapang.

Kalimantan Barat memiliki ibukota Provinsi bernama Kota Pontianak yaitu kota dengan jumlah penduduk sekitar 554.764 jiwa dan memiliki luas wilayah sebesar $107.82 \mathrm{~km}^{2}$. Di samping itu, Pontianak juga bersebelahan dengan Kabupaten yang sedang berkembang pesat saat ini dengan ekonomi dan pembangunan nya yaitu Kabupaten Kuburaya. Kedua kota tersebut merupakan kota dengan populasi etnis yang sama yaitu etnis Tionghoa, Dayak, Jawa, Bugis, Madura, Batak. Namun etnis yang dominan adalah etnis Melayu, maka dari itu dari etnis Melayu mereka banyak yang membentuk Organisasi Masyarakat (Ormas) yang berlandaskan budaya etnis Melayu untuk kegiatan sosial seperti Persatuan Orang Melayu Kalimantan Barat (POM), Komunitas Cinte Bahase Melayu Kalimantan Barat (CBMKB), dan ada sebuah Majelis Adat Budaya Melayu Kalimantan Barat (MABMKB). Majelis Adat Budaya Melayu tersebut merupakan wadah penaungan Budaya Kemelayuan di Kalimantan barat dan dipecah kepengurusannya di tiap kabupaten di Kalimantan Barat. Permasalahannya adalah minat regenerasi yang semakin berkurang, promosi budaya yang diselenggarakan seadanya, Kegiatan promosi kerajinan khas Melayu sulit dipasarkan, komunitaskomunitas Budaya Melayu yang belum memiliki tempat yang layak untuk diskusi tentang promosi Budaya Melayu Kalimantan Barat. Kesimpulan dari permasalahan tersebut adalah diperlukannya suatu wadah untuk melestarikan, memperagakan, mempertahankan dan mengembangkan Budaya Melayu Kalimantan Barat. Tempat yang cocok untuk menaungi berbagai aktivitas ini yaitu "Pusat Budaya Melayu Kalimantan Barat" yang memberikan tempat pelestarian Seni dan Budaya Melayu dengan konsep permukiman dalam wujud beberapa fasilitas penunjang kegiatan untuk edukasi, pameran, komersil, dan pelestarian budaya Melayu Kalimantan Barat.

\section{Kajian Pustaka}

Kebudayaan menurut beberapa para ahli. Menurut Koentjaraningrat (2000), mengatakan kebudayaan adalah keseluruhan manusia dari kelakuan dan hasil kelakuan yang teratur oleh tata kelakuan yang harus didapatnya dengan belajar dan kesemuanya tersusun dalam kehidupan masyarakat. Menurut Djojodiguno (1958), kebudayaan atau budaya adalah daya dari budi yang berupa cipta, karsa dan rasa. Guruvalah (2008), menyebutkan bahwa seni dapat diklasifikasikan kedalam kelompok berdasarkan bentuk dan mediumnya, yaitu seni rupa, seni sastra, seni musik, seni tari, dan seni teater dengan ciri-ciri masing-masing. Menurut Widyosiswoyo (2004), Dalam Bahasa Inggris, kebudayaan adalah culture, berasal dari kata culere (Bahasa Yunani) yang berarti mengerjakan tanah. Kata cultuur, dalam Bahasa Belanda masih mengandung pengertian pengerjaan tanah (ingat Culture Stelsel yang dilaksanakan pemerintah Belanda di Indonesia dalam abad XIX) dan sekaligus juga berarti kebudayaan seperti kata culture dalam Bahasa inggris.

Sebuah pusat budaya terdapat beberapa wadah dan kegiatan di dalamnya seperti ruang galeri dan pameran. Menurut Setiawan (2004), wadah merupakan sentra untuk sebuah komunitas memproduksi di bidang ekonomi. Pusat kebudayaan Melayu Kalimantan Barat sebagai wadah 
kegiatan pelestarian seni dan budaya yang terpadu meliputi kegiatan pemberian informasi, penelitian dan pengkajian, serta pagelaran atau pementasan yang bertujuan untuk melestarikan seni dan budaya Melayu, dengan fasilitas yang terpadu dalam satu kompleks bangunan untuk mempermudah pengawasan dan pengelolaan.

\section{Metode}

Perancangan ini menggunakan metode dari Whittaker (1993), yang terdiri dari tahap awal, tahap definisi, tahap persiapan, tahap analisis, tahap sintesis, tahap evaluasi dan tahap re-evaluasi. Pada tahap awal merupakan tahap mengangkat isu-isu terkait dari perancangan Pusat Budaya. Tahap definisi dimulai dari inti pembahasan dan berita yang beredar tentang kebudayaan Melayu di Kalimantan Barat dengan melakukan wawancara, studi lokasi, studi literatur dan data-data kerajinan Melayu. Tahap persiapan merupakan proses mengumpulkan data pokok yang didapat dari observasi ke lokasi secara langsung dengan cara melakukan proses wawancara terhadap orang sekitar maupun orang yang paham tentang lokasi namun bisa juga didapatkan dari data pemerintah atau data yang ada di literatur. Tahap analisis merupakan proses penyelesaian masalah yang dapat menghasilkan analisis pelaku, fungsi, bentuk, fisika bangunan, utilitas, struktur, tapak, dan lokasi. Tahap sintesis adalah hasil dari analisis yang dapat menghasilkan berupa penyelesaian konsep dasar tentang skematik ruang luar dan skematik ruang dalam secara kasar serta dapat membentuk tiga dimensi yang sekaligus menjelaskan struktur, bentuk dan fisika bangunan dari perancangan. Tahap evaluasi yaitu proses pembuatan konsep perancangan dan perencanaan dari awal hingga selesai. Tahap reevaluasi merupakan tahap terakhir yang berfokus pada proses dokumentasi perancangan seperti gambar structural, arsitektural, dan utilitas.

\section{Hasil dan Pembahasan}

Berdasarkan teori yang telah diuraikan, kriteria pembangunan Pusat Budaya yaitu harus dapat diakses dari semua bagian kota dengan transportasi umum maupun dapat diakses dengan berjalan kaki serta harus mudah dijangkau oleh para pelaku kesenian seperti pelajar, mahasiswa, komunitas, bahkan para tokoh kesenian di sekitaran lokasi. Berdasarkan analisa tersebut, lokasi yang dipilih sebagai lokasi perancangan Pusat Budaya Melayu Kalimantan Barat adalah lokasi di J1. Rais. A. Rahman, Kelurahan sungai jawi Kecamatan Pontianak Barat.

Di sisi Barat (kiri) site berbatasan dengan area permukiman warga. Sisi Utara (depan) site berbatasan dengan jalan raya utama yaitu Jl. H. Rais.A Rahman. Sisi Timur (kanan) site merupakan area pemukiman warga dan beberapa toko-toko sembako dan perabotan rumah tangga. Sisi selatan (belakang) site berhadapan langsung dengan rumah-rumah warga dan beberapa komplek perumahan baru. Menurut Rencana Tata Ruang Wilayah (RTRW) Kota Pontianak (2013) mengenai data peraturan lingkungan Koefisien Dasar Bangunan (KDB) pada area perancangan sebesar 20\%, Koefisien Lantai Bangunan (KLB) sebesar 0,8. Garis Sempadan Bangunan (GSB) sebesar 10 meter. Tautan lingkungan perancangan Pusat Budaya Melayu Kalimantan Barat disajikan pada Gambar 1. 


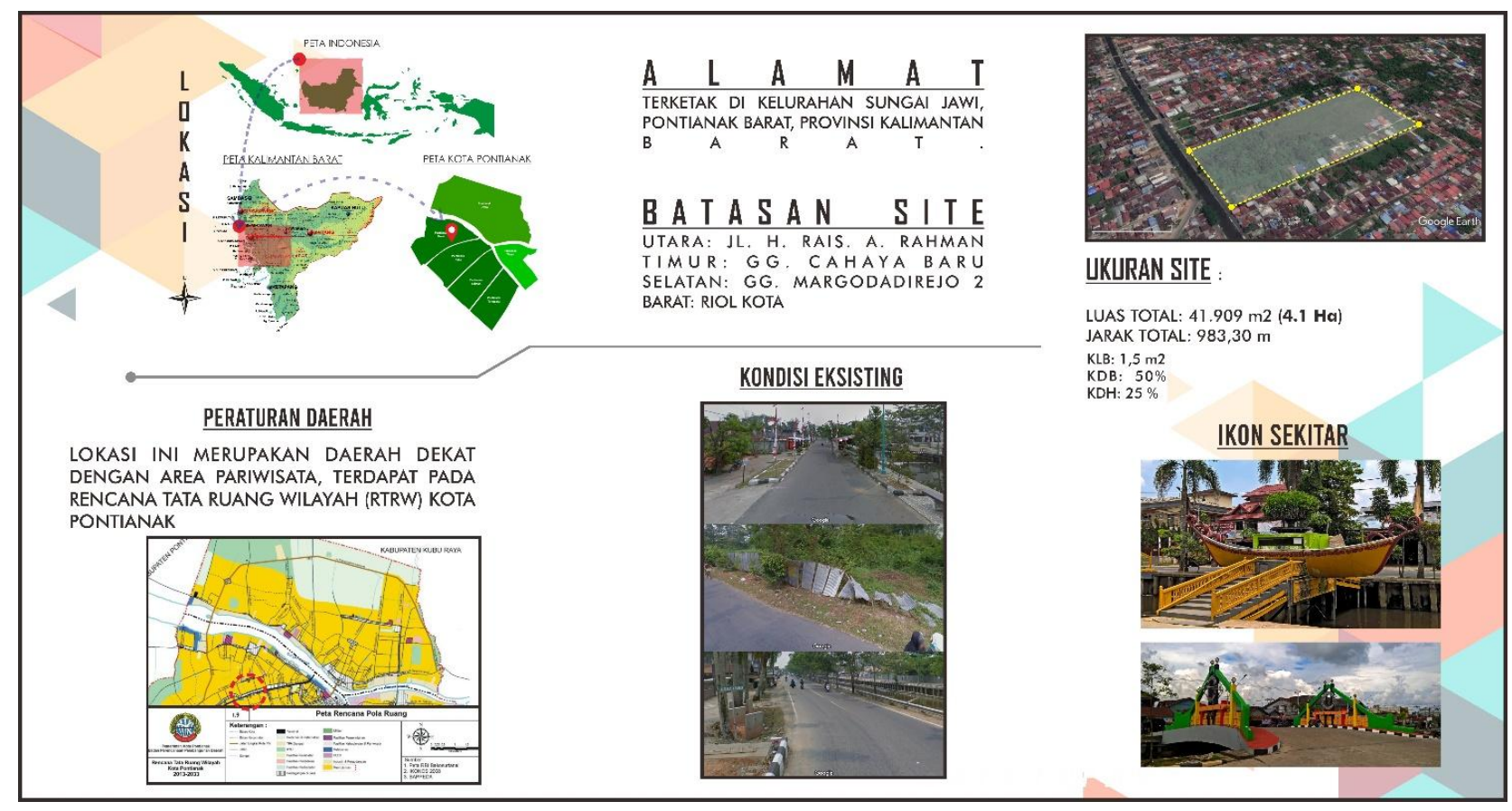

Gambar 1. Data Lokasi Pusat Budaya Melayu Kalimantan Barat

Sumber: Penulis, 2020

\section{Landasan Konseptual}

Pusat Budaya Melayu Kalimantan Barat menggunakan landasan yang menghasilkan konsep perencanaan dan perancangan. Proses untuk mendapatkan sumber permasalahan dan menemukan solusinya adalah melakukan analisa dan observasi langsung ke lokasi. Fungsi perancangan terbagi menjadi 4 fungsi, yaitu Ruang pertunjukkan, galeri seni, pengelola pusat budaya, dan ruang latihan. Fungsi pertunjukkan dan galeri seni di fungsikan untuk area publik yang menjadi fungsi primer dari perancangan ini. Fungsi pengelola dan galeri seni merupakan fungsi sekunder sebagai ruang pelayanan publik.

Analisis pelaku Pusat Budaya Melayu Kalimantan Barat pada dasarnya terdapat empat jenis kategori yaitu pelaku pengunjung sebagai penonton, pengunjung sebagai pementas, pengunjung sebagai tempat latihan dan pengelola. Pada pengunjung pementasan dan pengunjung latihan dapat dikerucutkan lagi yaitu pada pengunjung pementasan adalah budayawan, seniman dan komunitas sanggar. Pada pengunjung latihan dapat dikerucutkan lagi yaitu pengunjung yang berlatih menari, teater dan musik.

Analisis eksternal terbagi menjadi perletakan, zonasi, sirkulasi, orientasi dan vegetasi perancangan Pusat Budaya Melayu Kalimantan Barat. Konsep tapak dipengaruhi oleh data panca indera, iklim, dan keistimewaan alamiah di site. Data peraturan mengenai KDB, KDH, KLB dan GSB mempengaruhi tata letak bangunan yang lebih efektif dengan jumlah tunggal dan terpusat. Sistem pusat ini juga bertujuan untuk menghindari kebisingan terhadap bangunan serta untuk perolehan pandangan ke luar tapak secara merata. Analisis berdasarkan iklim menunjukkan pertimbangan cahaya matahari sehingga bangunan memanjang searah utara -selatan dengan lapangan yang disusun sejajar menghadap timur laut. Orientasi bangunan juga memperhatikan dari sirkulasi dan pandangan dari Jl. H. Rais. A Rahman untuk identifikasi bangunan oleh pengunjung. Hasil dari analisis menunjukkan bangunan dirancang dengan komposisi massa tunggal terpusat. Konsep tersebut dapat mengoptimalkan luas bangunan terhadap lahan perancangan. Daerah dalam garis sempadan (GSB) dapat dioptimalkan untuk parkir kendaraan, taman, dan lapangan.

Analisis tapak Pusat Budaya Melayu Kalimantan Barat terbagi menjadi perletakan, orientasi, sirkulasi, vegetasi, dan zonasi. Analisis Hasil peraturan meliputi KDB pada Site adalah 60\%, KLB 5, 
KDH $30 \%$, GSB terhadap Jl. H. Rais. A.Rahman 10 meter, GSB terhadap gang Cahaya 3.5 meter dan luas site $41.909 \mathrm{~m}^{2}$ atau 4.1 ha. Berdasarkan nilai tersebut, maka perletakan bangunan berada di pusat site dengan bentuk memanjang kea rah jl. H. Rais. A.Rahman.

Analisis Orientasi terbagi menjadi dua arah bukaan utama yaitu bukaan Primer dan Sekunder. Primer mengarah ke utara site dengan pertimbangan jalur sirkulasi tercepat untuk keluar atau masuk site dan masih mendapatkan cahaya dan view yang bagus. Sedangkan Sekunder mengarah ke barat laut dengan pertimbangan arah jalur keluar dan masuk ke site melalui jalur sekunder agar mempercepat kegiatan sirkulasi.

Vegetasi peneduh ditanam dengan tiga (3) area. Untuk area 1 ditanami pohon palem atau sejenisnya sebagai pengarah jalur sirkulasi keluar dan masuk site. Untuk area 2 ditanami pepohonan cukup tinggi dan rindang seperti pohon ketapang dan sejenisnya untuk melindungi dari efek sinar matahari berlebih ke bangunan. Untuk area 3 ditanami pepohonan yang tidak terlalu tinggi karena pada area ini merupakan area kegiatan outdoor atau ruangan terbuka umum.

Analisis zonasi terbagi menjadi 4 zona kawasan yaitu publik, semi publik, privat, semi privat, dan servis. Pada zona publik merupakan area kegiatan seperti perdagangan, taman, parkir, dan sejenisnya. Pada zona semi publik merupakan area fungsi sekunder dari Pusat Budaya Melayu seperti galeri terbuka, area diskusi, dan sejenisnya. Pada zona privat dan semi privat merupakan area fungsi pengelola Pusat Budaya Melayu seperti ruang karyawan, ruang tamu, galeri indoor, dan sejenisnya. Zona servis merupakan area yang dikhususkan fungsi servis dari bangunan seperti ruang genset, ruang keamanan, dan sejenisnya. Analis keseluruhan perancangan Pusat Budaya Melayu Kalimantan Barat disajikan pada Gambar 2.

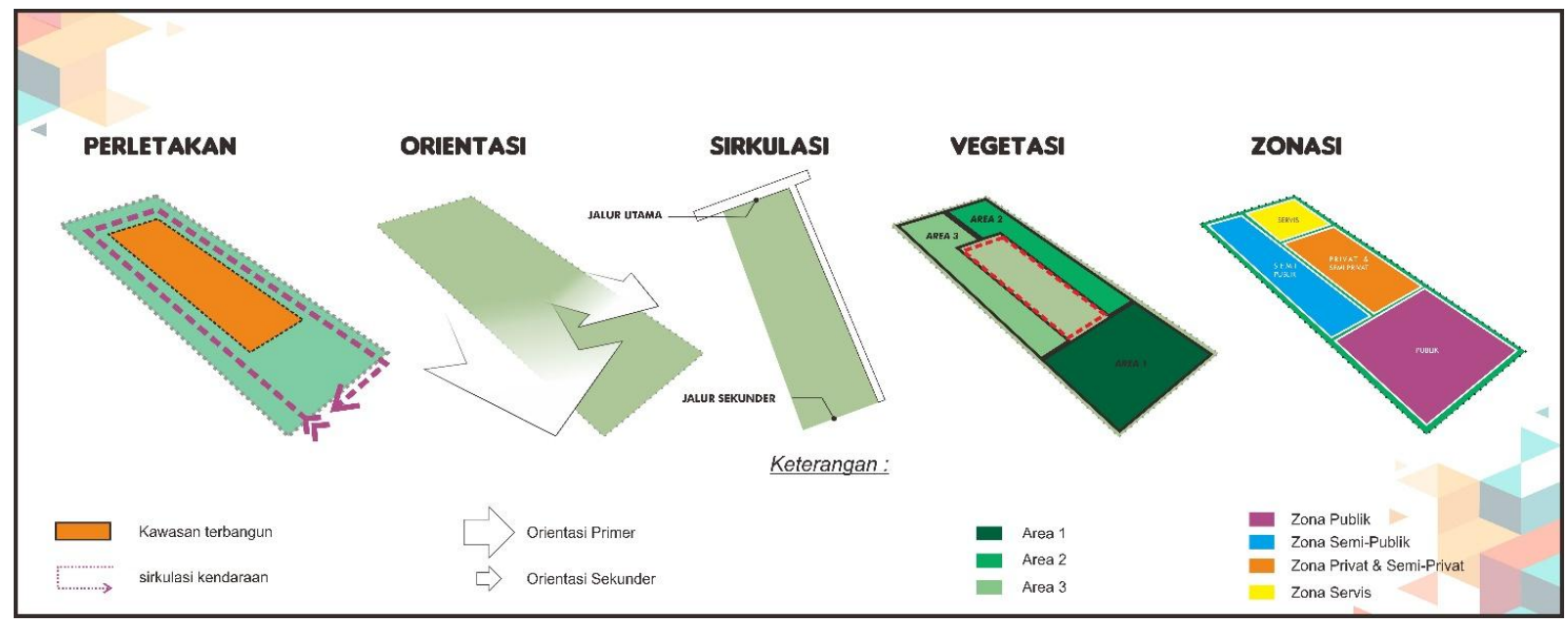

Gambar 2. Kesimpulan Analisis Tapak Pusat Budaya Melayu Kalimantan Barat Sumber: Penulis, 2020

Analisis bentuk berdasarkan bentuk-bentuk ruang dasar yang memiliki kondisi khusus disetiap fungsi. Fungsi pertunjukan, latihan, pengelola dan galeri memiliki bentuk berdasarkan penyusunan permukiman melayu. Fungsi yang sifatnya publik cenderung berbuka, luas, menarik, suasana kalem/ romantic dari pencahayaan, dan memiliki suasana budaya melayu. Fungsi pengelola cenderung memiliki bentuk ruang yang masif dan tidak menonjol, tidak lebar dan tidak tinggi serta banyak sekat ruang. Fungsi pertunjukkan cenderung memiliki bentuk ruang yang Panjang, luas dan bebas kolom. Fungsi latihan memiliki ruang latihan yang cenderung komunal dan privat secara kegiatan mereka didalamnya.

Berdasarkan wujud dasar ruang setiap fungsi, maka dapat diasumsikan besaran massa gubahannya berdasarkan jumlah besaran ruang yang terkait fungsi tersebut. Berikut merupakan urutan analisis bentuk yang didasari oleh analisis tapak yang disajikan pada Gambar 3. 


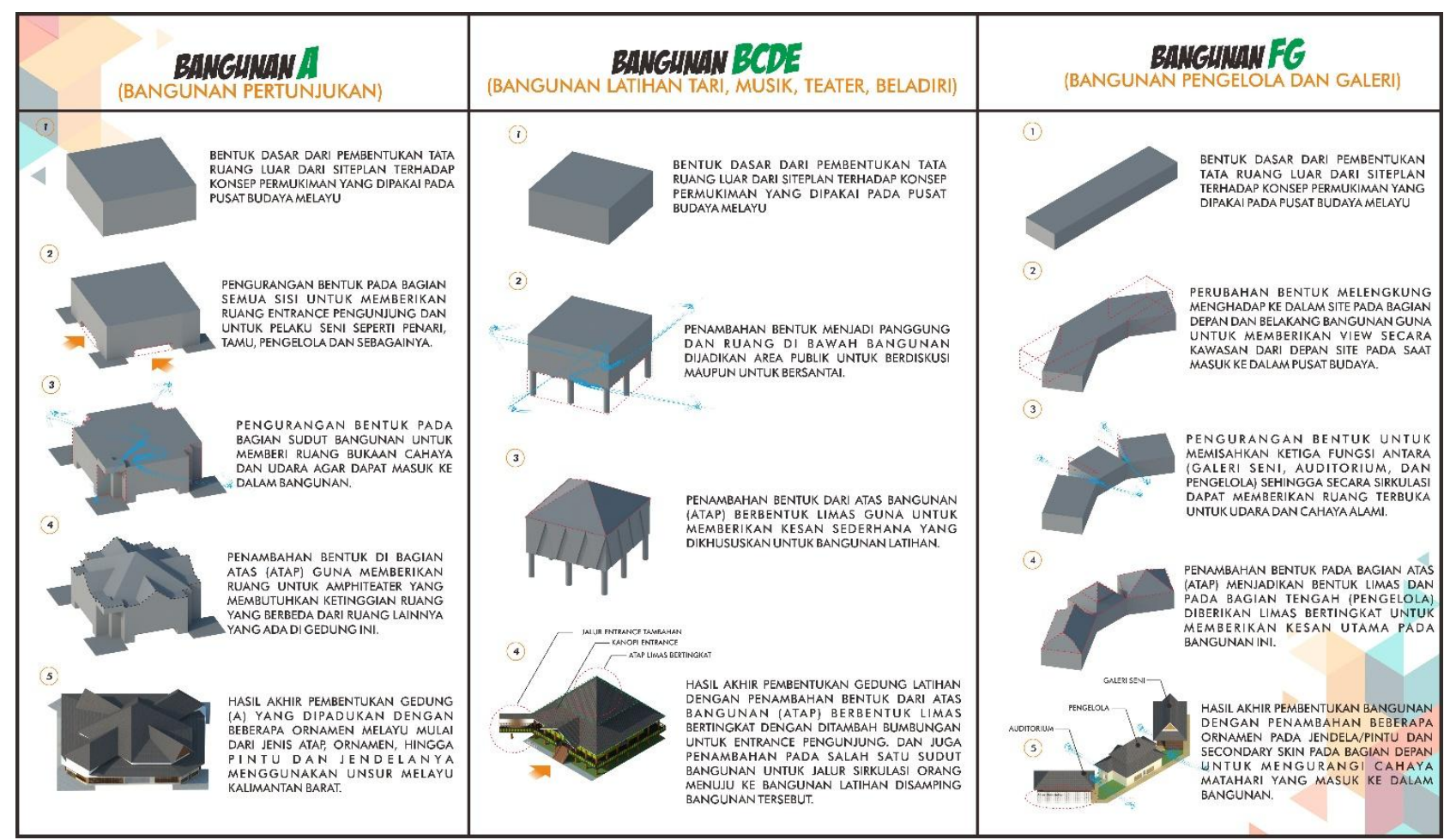

Gambar 3. Gubahan Massa Pusat Budaya Melayu Kalimantan Barat Sumber: Penulis, 2020

Konsep bentuk kawasan Pusat Budaya Melayu Kalimantan Barat menerapkan pola dasar dari permukiman melayu yang ada di pulau Kalimantan. Permainan ketinggian massa bangunan dari depan hingga belakang dimaksudkan dengan makna keberlanjutan silaturahmi yang tidak terputus atau terhalang oleh zaman. Konsep rumah panggung pada bangunan di tengah site sebagai ruang latihan dan pertunjukan terbuka karena ruang yang saling terhubung, kekeluargaan, serta tentram. Analis gubahan kawasan perancangan Pusat Budaya Melayu Kalimantan Barat disajikan pada Gambar 4.

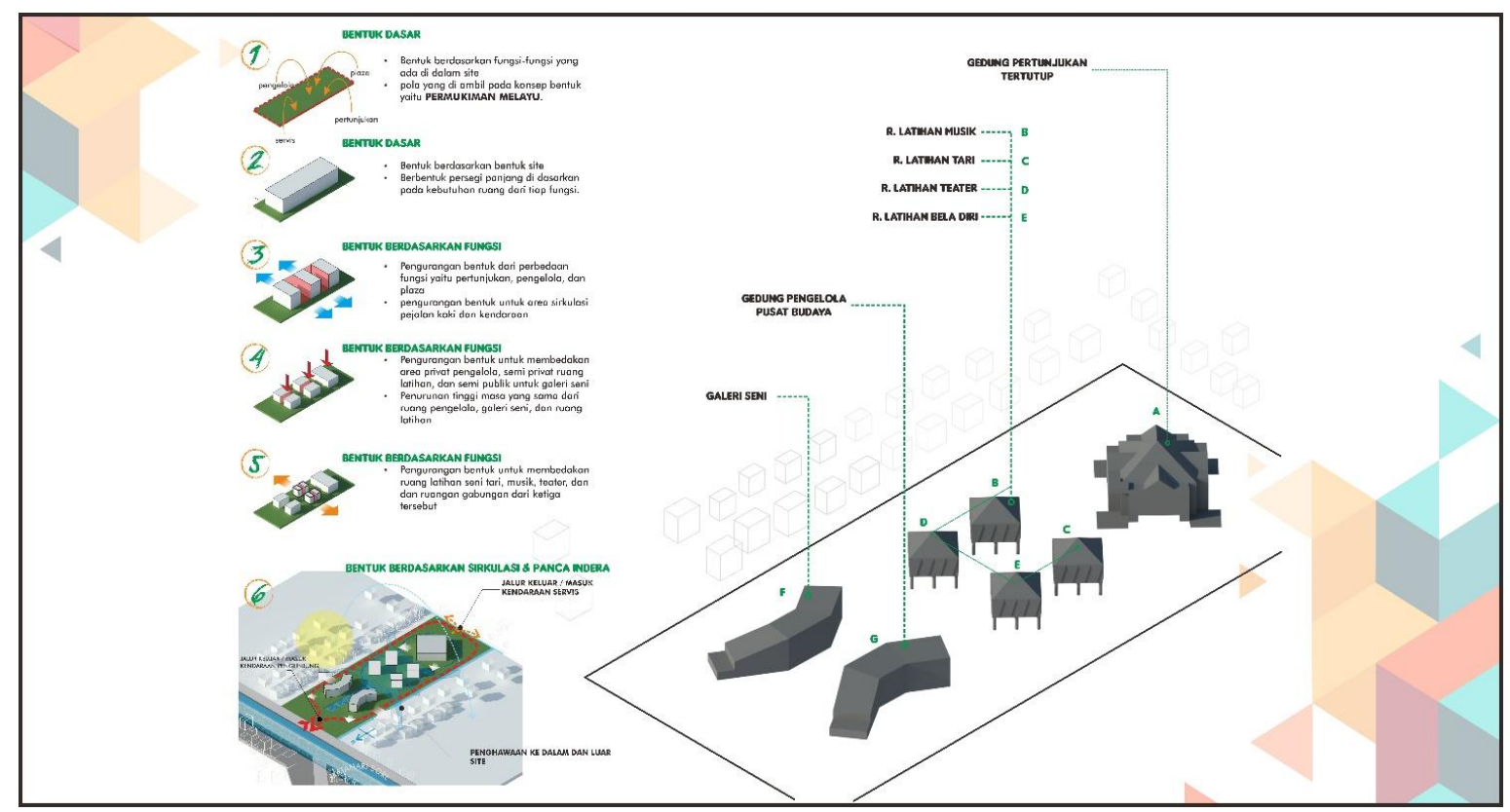

Gambar 4. Konsep Gubahan Bentuk Kawasan Pusat Budaya Melayu Kalimantan Barat Sumber: Penulis, 2020 
Konsep struktur bangunan Pusat Budaya Melayu Kalimantan Barat pada bangunan utama menggunakan sistem bentang lebar. Pada bagian gedung latihan, gedung pengelola dan gedung galeri seni menggunakan sistem bentang kecil. Pada perancangan Pusat Budaya Melayu memiliki dua sistem struktur yang berbeda dikarenakan pada bangunan utama difungsikan ruang yang bebas kolom dan ruang latihan yang memilikibentang yang cukup kecil. Pada sistem atap menggunakan sistem truss, menggunakan baja WF untuk kuda-kuda dan profil C. Pada bagian dinding perancangan menggunakan bahan umum yang digunakan yaitu bata ringan juga bata hebel, untuk lapis luar dinding menggunakan conwood (sejenis wallpaper) yang memiliki berbagai macam motif dan tekstur. Konstruksi lantai di cor beton yang ditutup dengan keramik, karpet, dan finishing semen aci. Konsep struktur perancangan Pusat Budaya Melayu Kalimantan Barat disajikan pada Gambar 5.

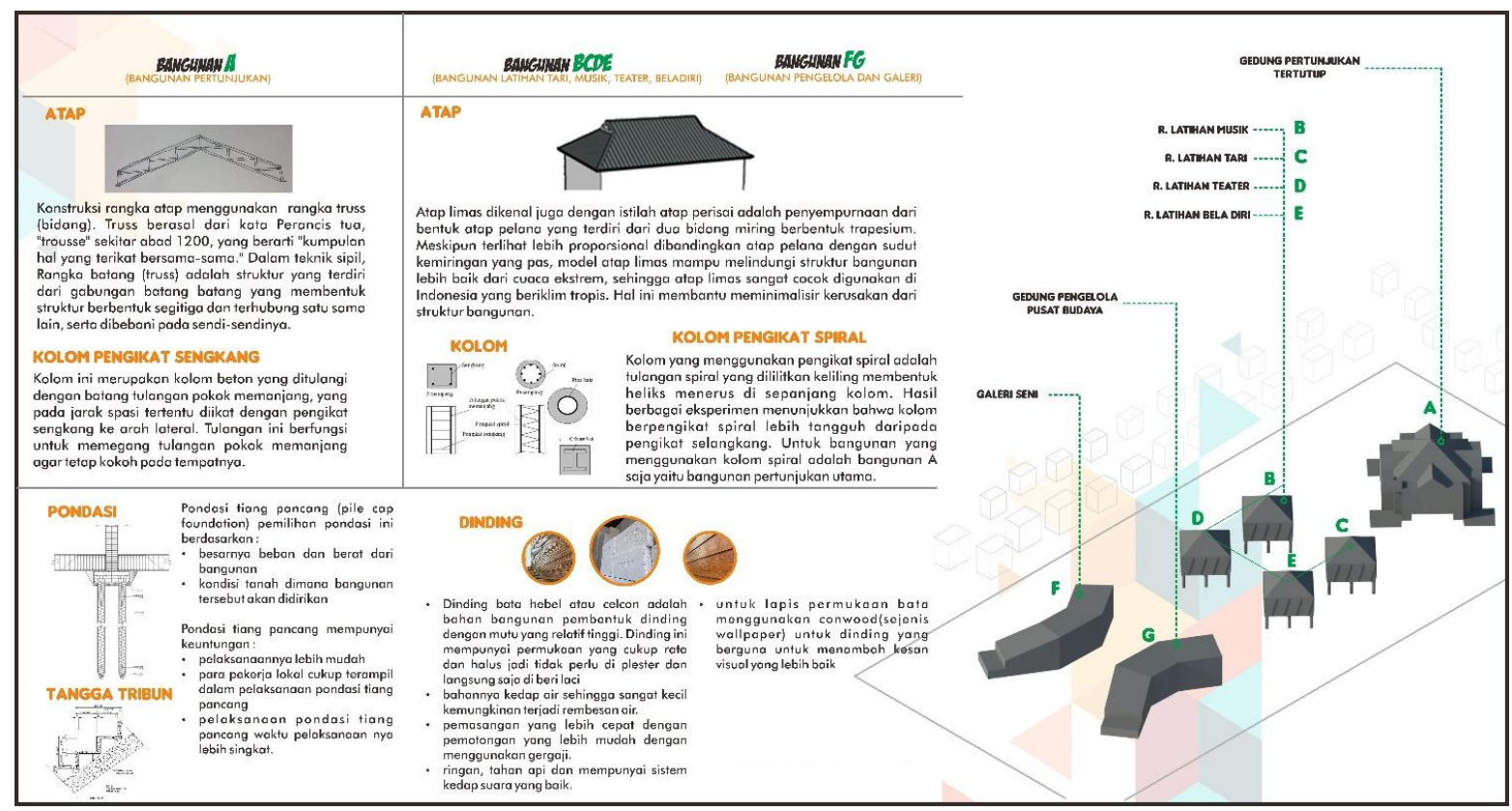

Gambar 5. Konsep Struktur Pusat Budaya Melayu Kalimantan Barat

Sumber: Penulis, 2020

Konsep utilitas Pusat Budaya Melayu Kalimantan Barat terdiri dari jaringan air bersih/kotor, listrik, HVAC, persampahan dan keamanan di dalam/luar bangunan. Pada jaringan air bersih menggunakan sistem down feed karena pada sistem ini menggunakan gravitasi sehingga tidak menguras listrik yang berlebihan. Pada sistem air bersih terdapat dua penampungan air bersih yaitu GWT, untuk penanggulangan kebakaran darurat dan untuk kebutuhan dari pengelola dan pengunjung. Pada sistem air kotor dialurkan dari sumber pembuangan air kemudian di arahkan ke grasetrap dan dibuang ke bak control kemudian ke STP dan paling akhir di alirkan ke roil kota atau pembungan air kotor setempat. Untuk sistem aliran kotoran berat dialirkan ke septic tank, kemudian ke STP dan ke arah riol kota atau pembungan khusus air kotor.

Sistem penerangan utama pada perancangan menggunakan LED Lamp. Jaringan CCTV (indoor) menggunakan CCTV satu arah dan dan untuk ruangan yang luas (outdoor) seperti lapangan, taman, dan sejenisnya CCTV radius $360^{\circ}$. Jaringan Komunikasi seperti telepon dan wifi menggunakan sumber dari Telkom yang tersalur dari PABX. Terakhir untuk instalasi speaker di dapat dari aliran PLN yang di salurkan ke tiap speaker yang ada di indoor maupun outdoor.

Sistem keamanan bangunan menggunakan tiang penangkal petir yang memiliki tinggi sekitar 6 meter dan kisaran luasan lindung yaitu sekitar 100-150 meter. Peletakan tangga darurat berjarak 25 
meter setiap unit tangga dan memiliki radius jangkauan maksimal $30 \mathrm{~m}$. Analis konsep utilitas perancangan Pusat Budaya Melayu Kalimantan Barat disajikan pada Gambar 6.

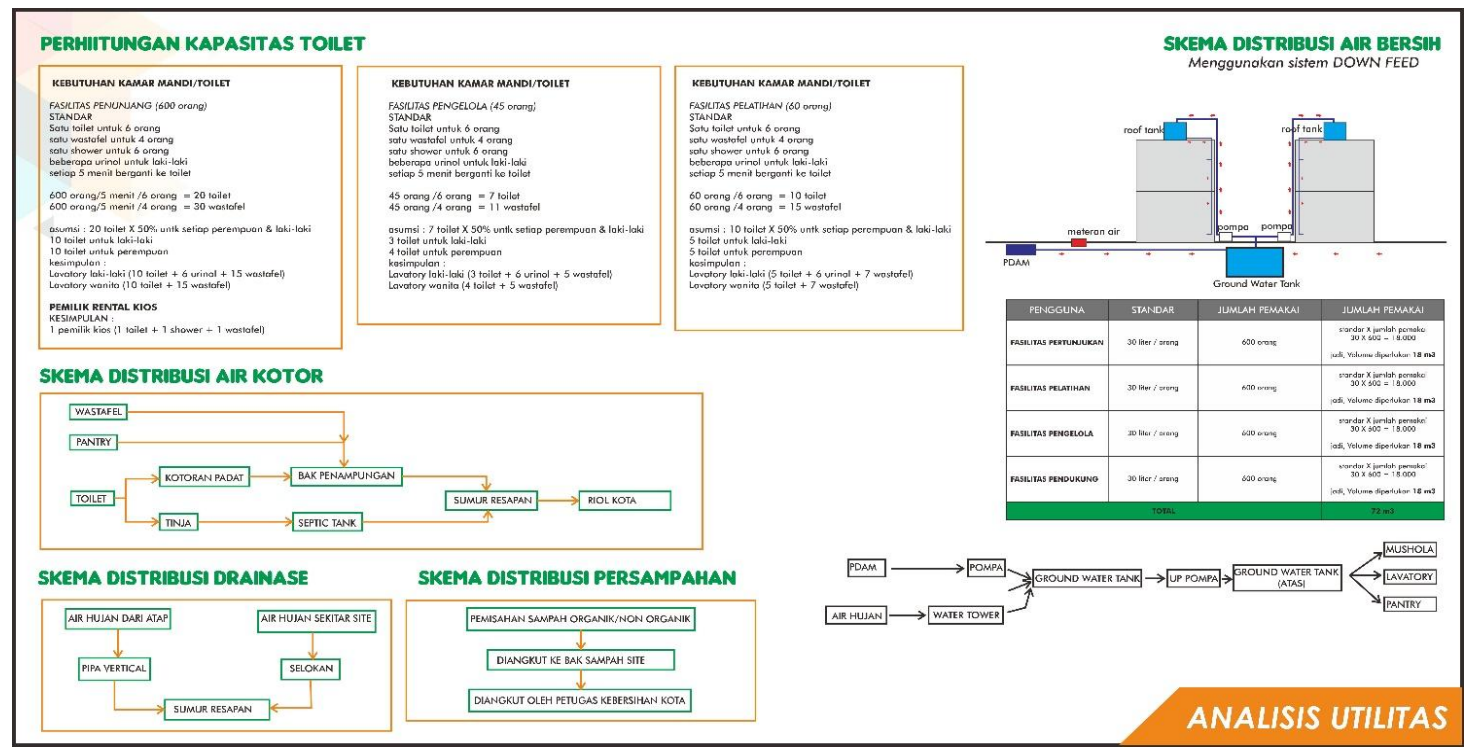

Gambar 6. Konsep Utilitas Pusat Budaya Melayu Kalimantan Barat

Sumber: Penulis, 2020

Sistem penghawaan alami pada perancangan Pusat Budaya Melayu Kalimantan Barat memanfaatkan bukaan jendela yang besar dan memungkinkan untuk udara alami masuk dengan mudah ke dalam bangunan. Sedangkan sistem penghawaan buatan di letakkan pada ruangan yang memiliki sifat ruang privat dan semi privat seperti pengelola, ruang latihan, dan sejenisnya. Menurut Schirmbeck (1988), pencahayaan alami untuk besar bukaan minimal yaitu maksimal 10\% dari luas dinding. Analis fisika bangunan perancangan Pusat Budaya Melayu Kalimantan Barat disajikan pada Gambar 7.

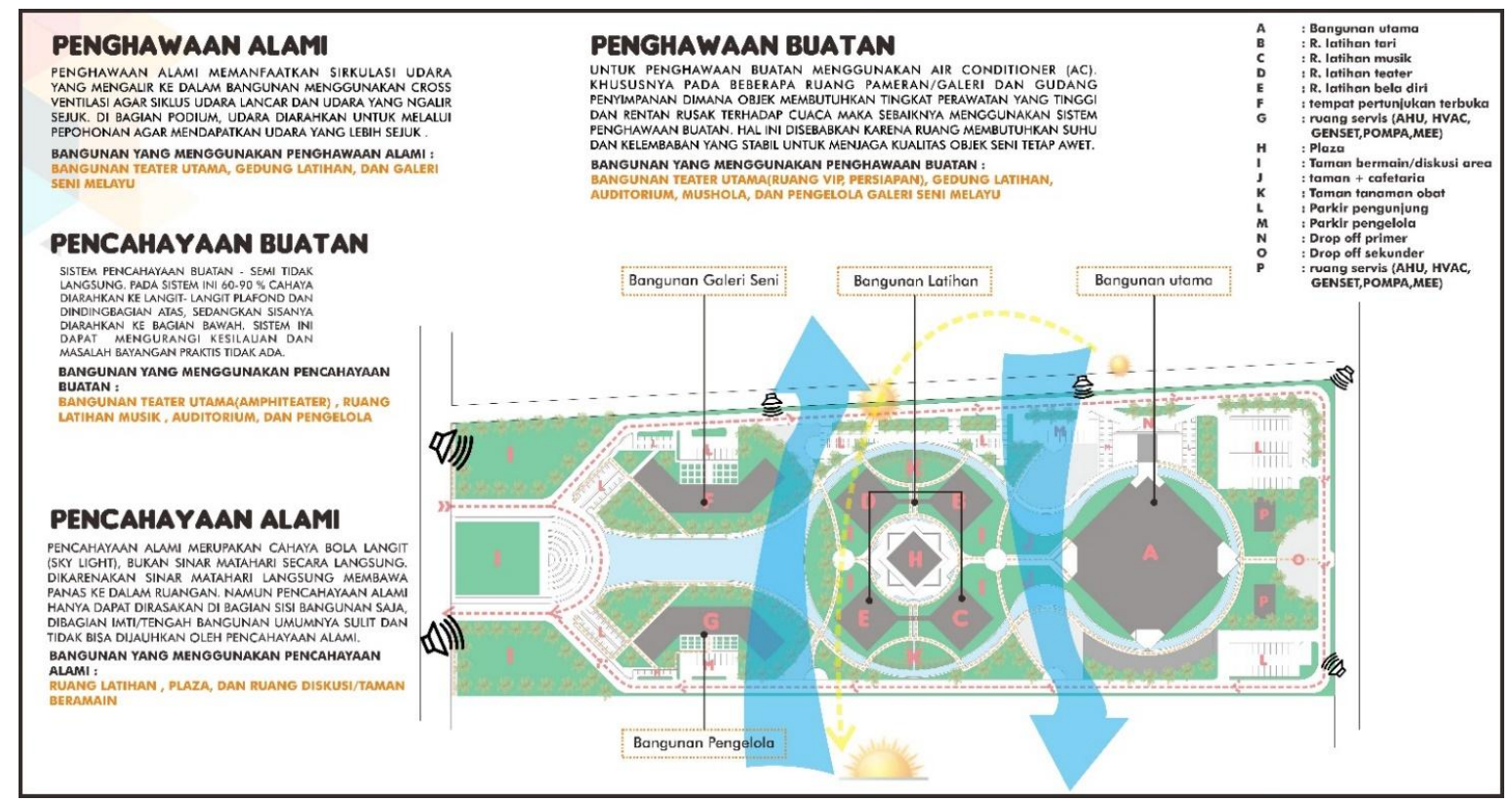

Gambar 7. Konsep Fisika Bangunan Pusat Budaya Melayu Kalimantan Barat Sumber: Penulis, 2020 


\section{Hasil Perancangan}

Perancangan ini memperoleh hasil gambar pra-rancangan Pusat Budaya Melayu Kalimantan Barat meliputi bangunan utama yaitu Gedung pertunjukkan tertutup dan area kawasan berupa Gedung Latihan, Gedung Pengelola, Galeri seni, area parkir, taman, cafeteria, dan ruang pertunjukkan terbuka . Pusat Budaya Melayu Kalimantan Barat mempunyai empat gedung utama yaitu gedung utama, gedung latihan, gedung pengelola dan gedung galeri seni. Siteplan perancangan Pusat Budaya Melayu Kalimantan Barat disajikan pada Gambar 8.

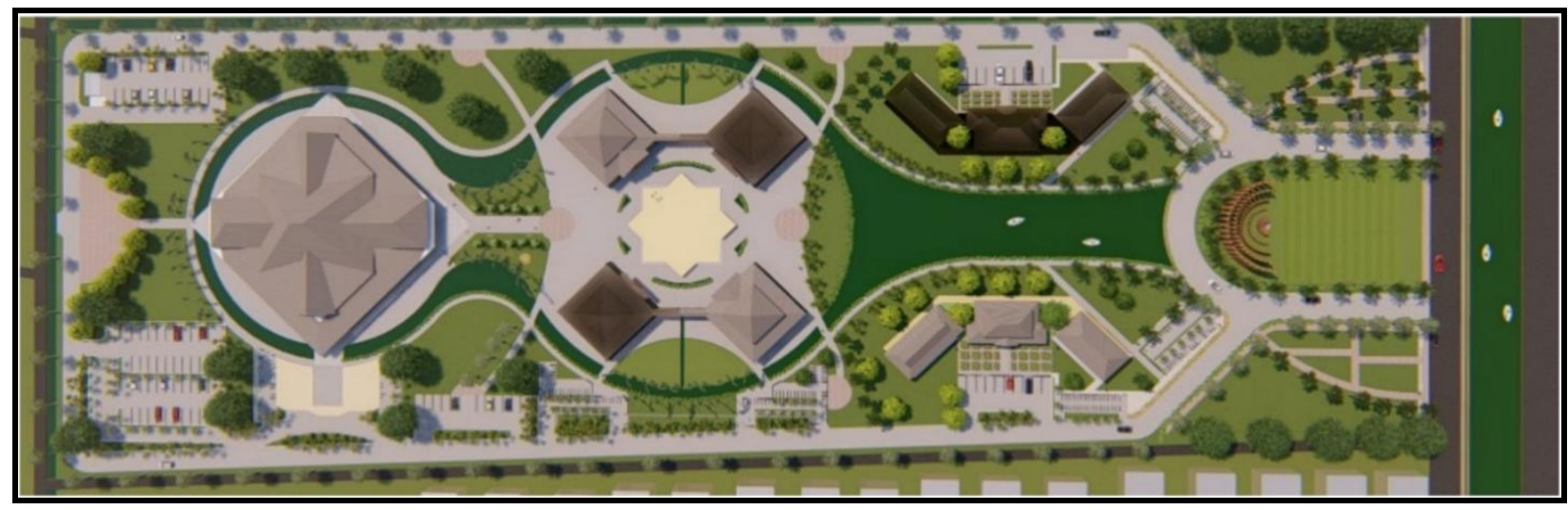

Gambar 8. Site Plan Pusat Budaya Melayu Kalimantan Barat

Sumber: Penulis, 2020

Pusat Budaya Melayu Kalimantan Barat mempunyai empat gedung yaitu bangunan A (amphitheater), bangunan B, C, D, E (latihan), bangunan F (pengelola) dan bangunan G (galeri seni). Jumlah denah dari setiap bangunan hampir sama yaitu satu lantai. Gambar denah lantai satu bangunan A disusun oleh ruang publik (ruang pameran, amphitheater dan lobby). Gedung pertunjukkan tertutup disusun oleh ruang semi privat (ruang tiket, ruang persiapan dan side stage), ruang privat (ruang VIP dan ruang rias/kostum) dan servis. Denah lantai dasar bangunan A perancangan Pusat Budaya Melayu Kalimantan Barat disajikan pada Gambar 9.

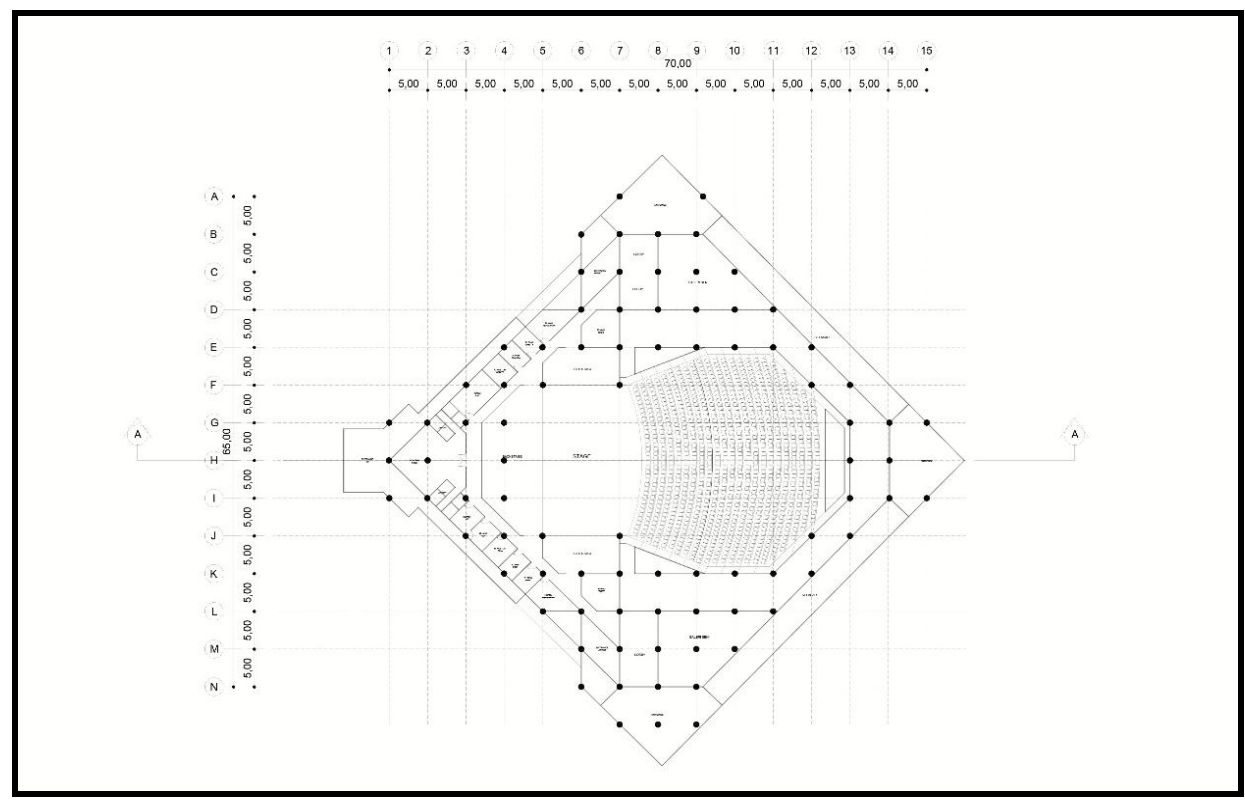

Gambar 9. Denah Bangunan A (Pertunjukkan Tertutup) Pusat Budaya Melayu Kalimantan Barat Sumber: Penulis, 2020 
Denah bangunan B, C, D, dan E yaitu ruang latihan yang denah nya tipikal. Gambar denah lantai satu bangunan $\mathrm{B}, \mathrm{C}, \mathrm{D}$, dan $\mathrm{E}$ disusun oleh ruang latihan, teras dan area diskusi. Zona semi privat (ruang diskusi, ruang persiapan dan panggung), zona privat (ruang alat dan ruang rias/kostum) dan zona servis (gudang dan toilet). Denah lantai dasar bangunan B, C, D, dan E perancangan Pusat Budaya Melayu Kalimantan Barat disajikan pada Gambar 10.

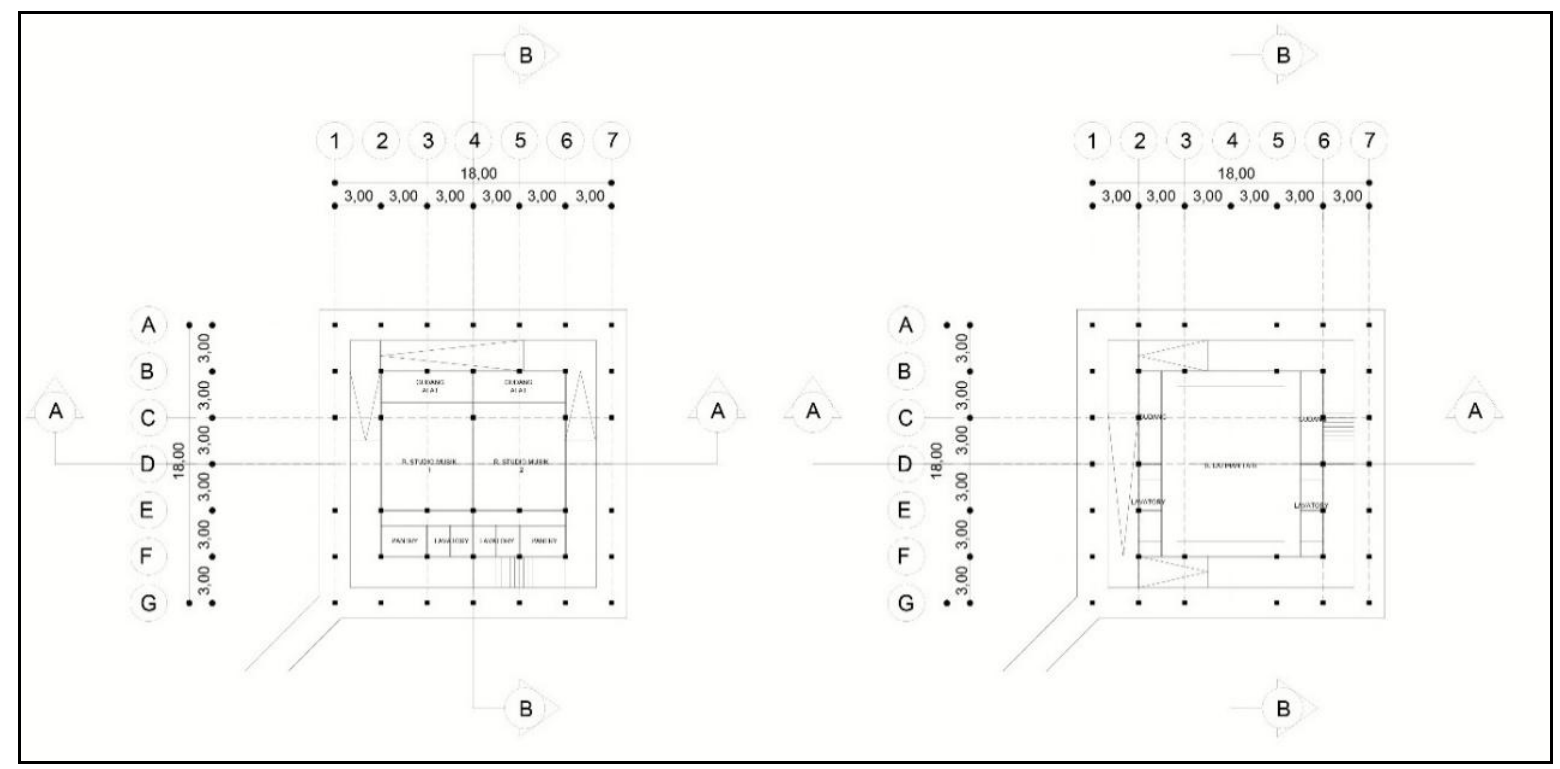

Gambar 10. Denah Bangunan B, C, D, dan E (Ruang Latihan) Pusat Budaya Melayu Kalimantan Barat

Sumber: Penulis, 2020

Tampak samping kiri dan kanan kawasan Pusat Budaya Melayu Kalimantan Barat merupakan bentuk dari konsep permukiman melayu di kalimantan. Gedung A merupakan titik akhir dari permukiman dan merupakan bangunan utama yang ada di perancangan ini. Fasad bangunan keseluruhan memiliki kesamaan dari ornamen dan bentuknya. Atap bangunan galeri seni dan pengelola sengaja dibuat lebih rendah dan bangunan latihan sedang serta yang terakhir bangunan pertunjukan lebih tinggi yang di artikan sebagai tanda hormat dan "regenerasi". Tampak kawasan perancangan Pusat Budaya Melayu Kalimantan Barat disajikan pada Gambar 11.

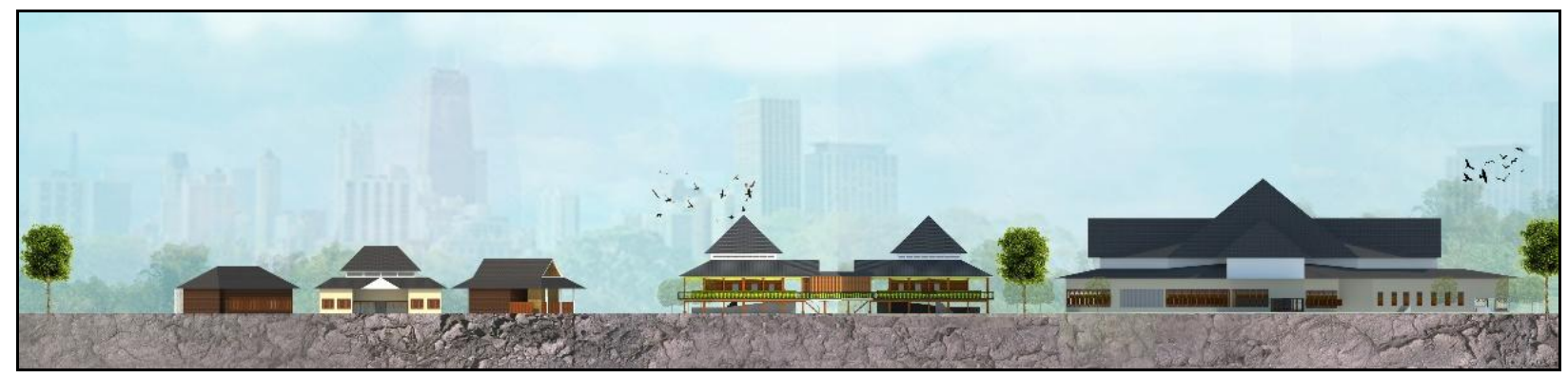

Gambar 11. Tampak Samping Kiri Kawasan Pusat Budaya Melayu Kalimantan Barat Sumber: Penulis, 2020

Potongan (A-A) menjelaskan ruang yang ada di bangunan A atau bangunan utama. Ruang yang di potong pada gambar yaitu ruang amphitheater, lobby, ruang tiket, dan ruang persiapan. Untuk tinggi dari lantai hingga plafon pada gedung utama yaitu 5 meter, ketinggian gedung secara keseluruhan yaitu 19 meter. Potongan (B-B) menjelaskan ruang amphitheater ruang persiapan, lobby dan selasar. Dari kedua potongan ini dapat memperlihatkan bahwa gedung ini memiliki banyak zona 
publik dan memiliki kebutuhan ruang yang cukup besar dan dapat menampung banyak pengunjung. Gambar potongan bangunan utama perancangan Pusat Budaya Melayu Kalimantan Barat disajikan pada Gambar 12 dan Gambar 13.

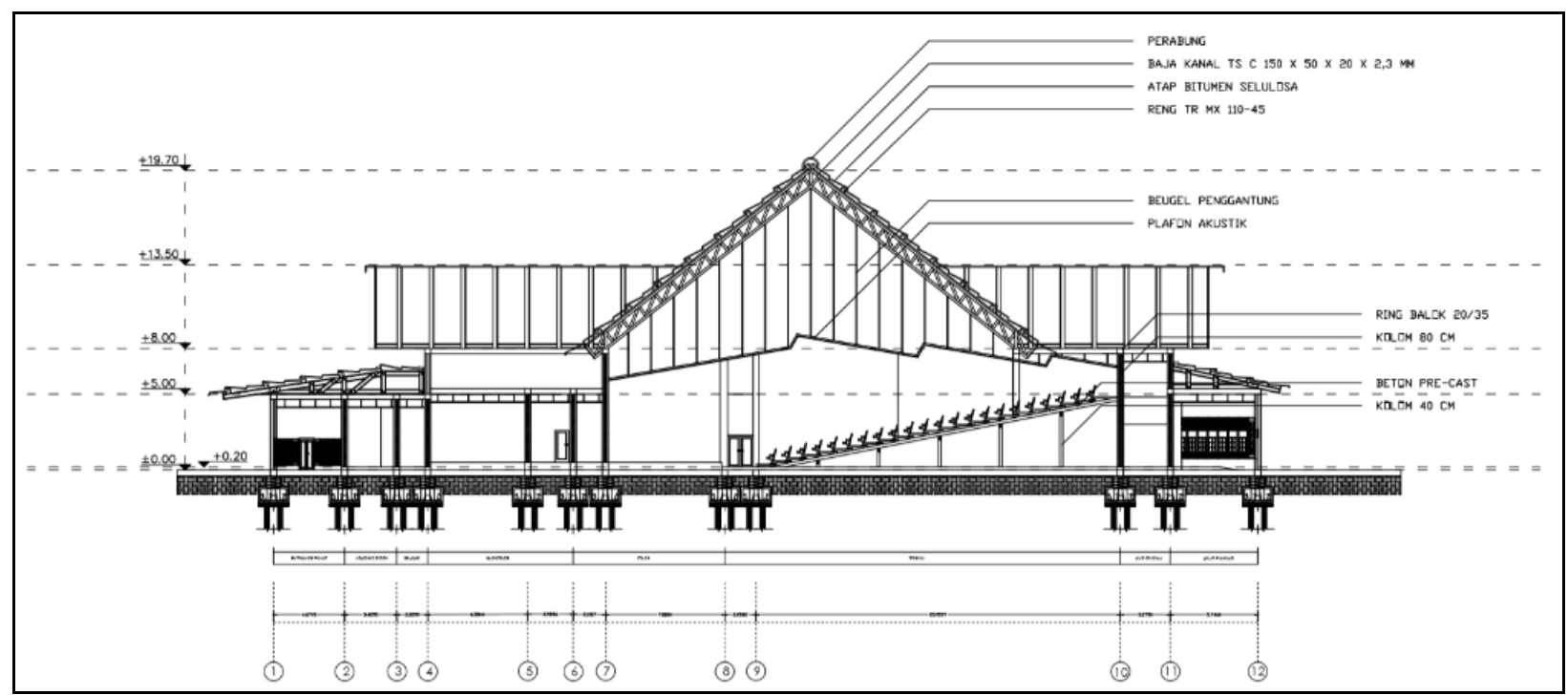

Gambar 12. Potongan A-A Pusat Budaya Melayu Kalimantan Barat

Sumber: Penulis, 2020

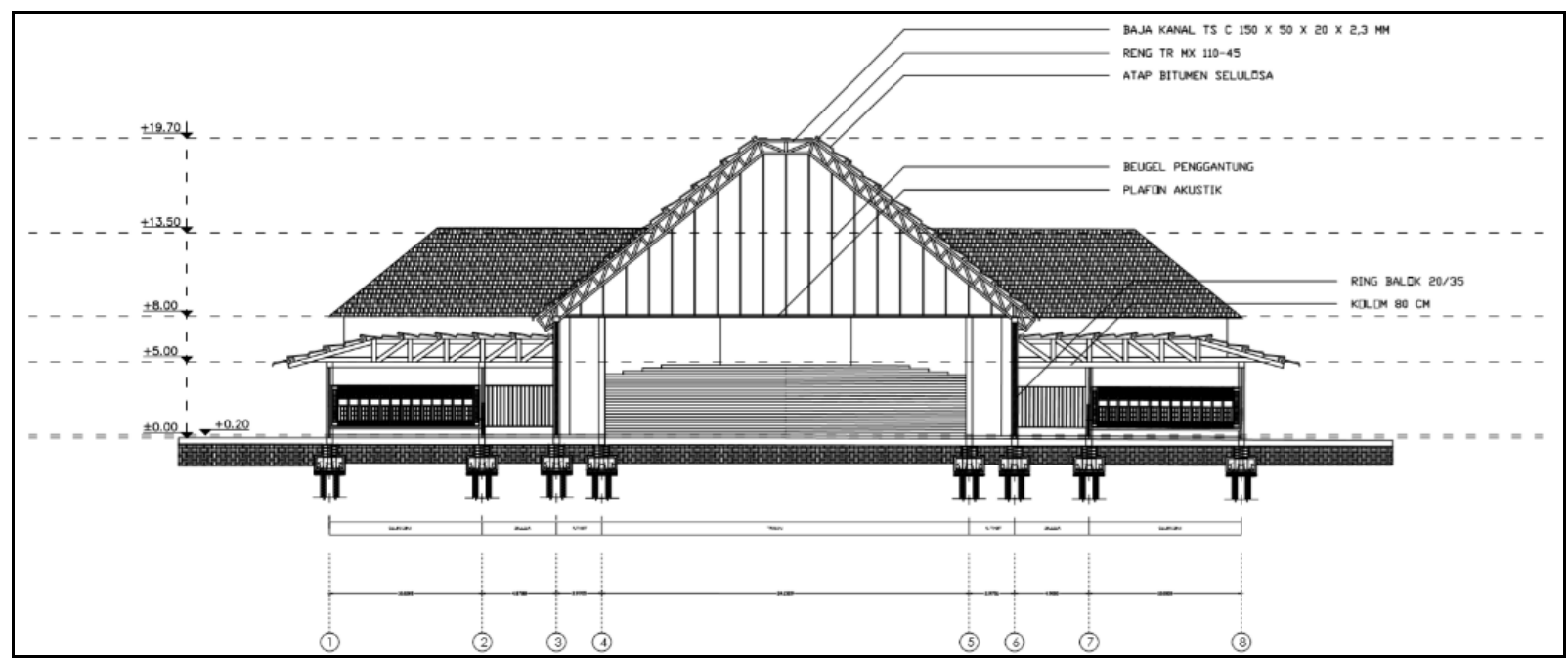

Gambar 13. Potongan B-B Pusat Budaya Melayu Kalimantan Barat Sumber: Penulis, 2020

Pada gambar eksterior dan interior pada perancangan dan tampilan kawasan Pusat Budaya Melayu Kalimantan Barat bersifat saling terhubung. Permukiman ini akan menjadi pusat aktivitas baru bagi warga sekitar dan akan menjadi daya tarik baru untuk wisatawan karena tersedia ruang seperti plaza (pertunjukan terbuka), ruang pertunjukan tertutup, area diskusi dan danau buatan. Pola permukiman dari kawasan mengadopsi permukiman melayu dengan pola terpusat pada bangunan utama yaitu bangunan pertunjukan tertutup (bangunan A). Dari bentuk bangunan kawasan memiliki bentuk yang berbeda-beda dikarenakan kebutuhan yang diperlukan juga berbeda namun memiliki kesamaan dari segi ornament budayanya. Dari segi orientasi, warna, dan motif yang digunakan memiliki keseragaman menandakan bahwa kawasan perancangan ini merupakan satu kesatuan budaya meskipun memiliki kegiatan yang berbeda. Warna dominan pada setiap bangunan yaitu warna kuning telur dan hijau daun pandan sebagai simbol utama warna khas Melayu Kalimantan 
Barat, sehingga menciptakan nuansa yang hangat pada pengunjung dan para pelaku utama dalam kawasan Pusat Budaya Melayu Kalimantan Barat. Gambar susasana eksterior dan interior dari perancangan Pusat Budaya Melayu Kalimantan Barat disajikan pada Gambar 14.

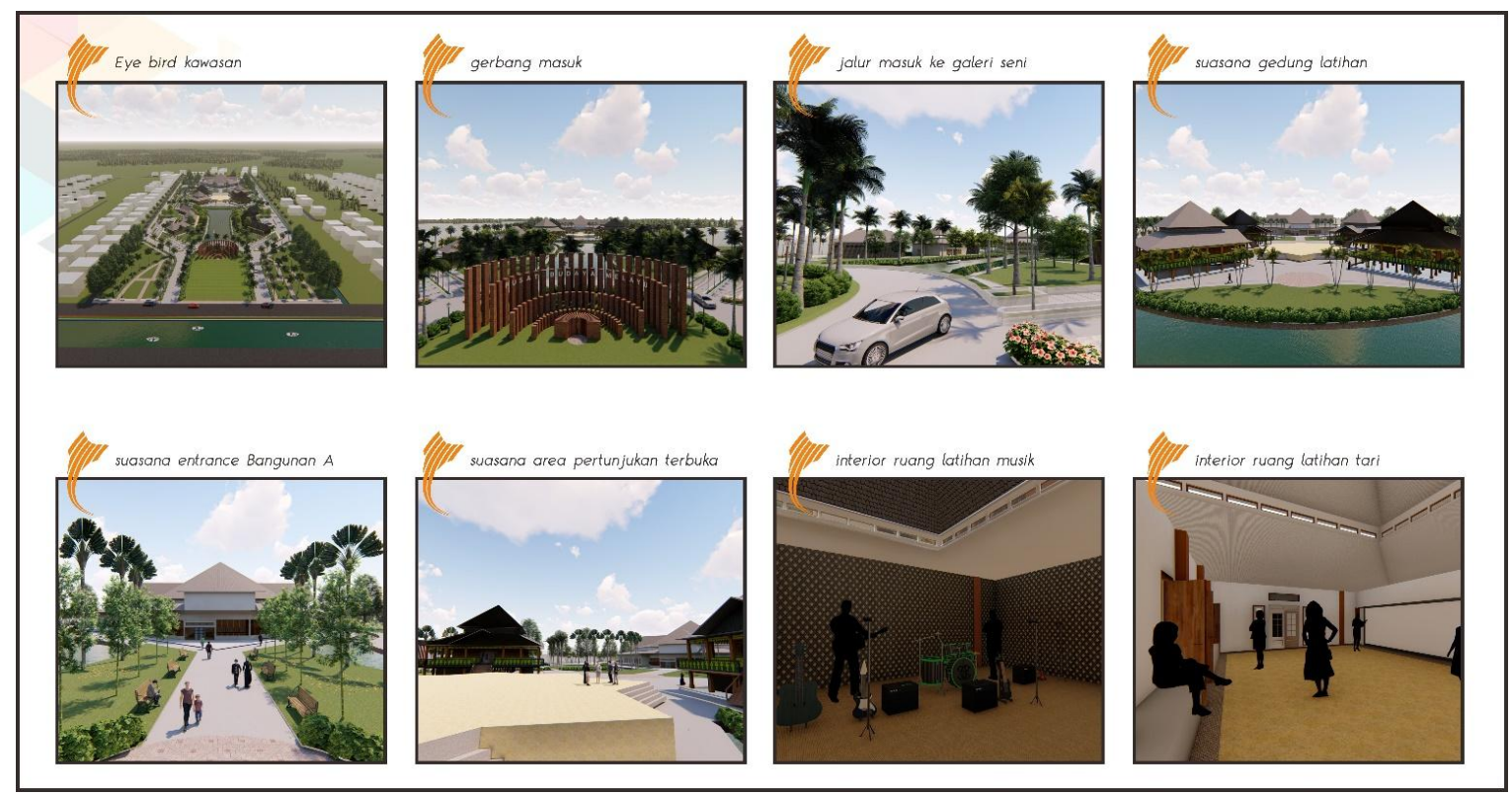

Gambar 14. Suasana Eksterior dan Interior Pusat Budaya Melayu Kalimantan Barat Sumber: Penulis, 2020

\section{Kesimpulan}

Pusat Budaya Melayu Kalimantan Barat menjadi tempat untuk melestarikan/mewarisi, mengolah, dan memasarkan produk budaya melayu asli dari Kalimantan Barat. Membuat permukiman sekitar menjadi tumbuh bersama untuk mewarisi budaya Melayu Kalimantan Barat dengan membuat kegiatan dan memamerkan kerajinan khas Melayu. Konsep perancangan dengan wujud permukiman memiliki suasana budaya, kekeluargaan, dan ramah. Mewujudkan keinginan para pelaku budaya dalam bentuk fasilitas untuk bersikusi, memamerkan, melestarikan dan mengenalkan kepada dunia bahwa Budaya Melayu Kalimantan Barat memiliki banyak keunikan tersendiri. Sehingga Pusat Budaya Melayu Kalimantan Barat dapat menciptakan lingkungan permukiman yang di inginkan oleh banyak orang sebagai tempat untuk melestarikan budaya mereka.

\section{Ucapan Terima Kasih}

Penulis memberikan banyak ucapan syukur kepada Tuhan Yang Maha Esa, kepada kedua orang tua, kerabat/keluarga, teman-teman dan dosen pembimbing yang telah membantu dalam proses penyelesaian perancangan ini.

\section{Daftar Acuan}

Djojodiguno. (1958). Asas-asas sosiologi. Jogjakarta: Gadjah Mada

Guruvalah. (2008). Pengertian Kebudayaan dan Seni. Samarinda: Sugiarto Darmali

Koentjaraningrat, K.P. H. (2000). Manusia dan Kebudayaan di Indonesia. Jakarta: Djambatan

Schirmbeck, E. (1998). Gagasan, Bentuk dan arsitektur: Prinsip-Prinsip Perancangan dalam Arsitektur Kontemporer. Bandung: Intermatra

Sekretariat Daerah Kota Pontianak. (2013). Peraturan Daerah Kota Pontianak Nomor 2 Tahun 2013 tentang Rencana Tata Ruang Wilayah Kota Pontianak Tahun 2013-2033. Pontianak: Sekretariat Daerah Kota Pontianak

Setiawan, G. (2004). Implementasi Dalam Birokrasi Pembangunan. Bandung: Remaja

Whittaker, B. J. (1993). Metode for strategic planning and Performance Measurement. Jakarta: Gapurapritama (GPRA) Widyosiswoyo, M. S. (2004). Ilmu Budaya Dasar. Jakarta: Ghalia Indonesia 